\title{
The Sa Chog
}

Violence and veneration in a Tibetan soil ritual

Le sa chog. Violence et vénération dans un rituel tibétain du sol

\section{Alexander Gardner}

\section{(2) OpenEdition}

Journals

Electronic version

URL: https://journals.openedition.org/emscat/1068

DOI: $10.4000 /$ emscat. 1068

ISSN: 2101-0013

\section{Publisher}

Centre d'Etudes Mongoles \& Sibériennes / École Pratique des Hautes Études

\section{Printed version}

Date of publication: 1 May 2006

Number of pages: $283-323$

ISBN: 2-9518888-3-X

ISSN: 0766-5075

\section{Electronic reference}

Alexander Gardner, "The Sa Chog", Études mongoles et sibériennes, centrasiatiques et tibétaines [Online], 36-37 | 2006, Online since 23 March 2009, connection on 13 July 2021. URL: http://

journals.openedition.org/emscat/1068 ; DOI: https://doi.org/10.4000/emscat.1068

This text was automatically generated on 13 July 2021

(c) Tous droits réservés 


\title{
The Sa Chog
}

\author{
Violence and veneration in a Tibetan soil ritual \\ Le sa chog. Violence et vénération dans un rituel tibétain du sol
}

Alexander Gardner

\section{AUTHOR'S NOTE}

I am grateful to Donald Lopez, E. Gene Smith and Stéphane Arguillère for their assistance in preparing this article and to Marie-Lise Beffa and Katia Buffetrille for their comments and thorough editing of this paper.A recent article by Cathy Cantwell of Oxford University in Revue d'Études Tibétaines ("The Earth Ritual: Subjugation and Transformation of the Environment," April 2005, pp. 4-21) that deals with an extended version of this step appeared too late for me to fully respond to. The article deals with a version of the sa chog that is performed prior to retreats and to the drawing of initiation mandala. See note 10 for a brief discussion of the ritual discussed in this article. Cantwell is chiefly concerned with the interaction of the ritualist and the goddess of the earth, who, she explains, is called by the ritual master to affirm his authority to use the site just as the Buddha called her at the conclusion of his battle with Mara. Following this the site is then cleansed and the practitioner takes possession of it. Cantwell's presentation of the rite provides the ritualist with no adversary

-Mara, she states, is here absent-thus making difficult an explanation of the violence she rightly states is explicit in the sa chog ritual.

In fact, the fields and their products are considered as eminently alive. There resides in

them a religious principle that slumbers in winter, reappears in spring, is manifested in the

harvest, and thus makes harvest difficult for mortals to enter upon. Sometimes this principle is even represented as a spirit that mounts guard 
over the earth and its fruits. It is their sanctity. It must therefore be eliminated in order that the harvest and the use of the crops be made possible. But at the same time, since it is the very life of the field, after having been expelled it must be recreated and fixed in the earth whose fertility

it produces.

(Hubert and Mauss 1964, pp. 66-67)

1 According to the seventeenth-century Tibetan author Karma chags med, when preparing to construct "a funeral pyre, temple, stūpa, castle and so forth, there is need of a soil ritual (sa chog) to properly reckon with the serpent (lto 'phye)." $B y$ means of the sa chog an autochthonous serpentine deity is drawn up from the subterranean darkness and made to listen to the demands of human beings desiring to take possession of its land. Complex astrological calculations are combined with tantric ritual to assert human mastery over the natural environment, aligning earth and sky with the demands of human geography. This is done to a large degree in accordance with a traditional Buddhist subjugation narrative, in which the deity is called forth, killed, revived, venerated, and thereby placed in service to the Buddhist community.

There is a tension in the sa chog, the product of the need to combine disparate, and in a sense contradictory, elements of ritual practice. The deity is both killed and venerated, dominated and deferred to. Offerings are made, but no victim is sacrificed. As the very fecundity of the earth, the deity is literally the foundation of human society. But its power is unpredictable and dangerous, and like wild open space it must be organized and defined to be of use. The sa chog thus combines subjugation and worship, fertility rites with ritual killing, and plays with the resulting tensions as a means to both affirm the power of the soil and assert human mastery over that power.

The sa chog rite does not simply affirm a social ideal (human mastery over nature) inside a closed ritual space, while the society and world outside continues unaltered. The sa chog has a localized impact wherever it is performed, and that is the organization of space. The sa chog is a means by which human invaders insert themselves into a new landscape, be it a new valley or a new continent. As in Buddhist subjugation myths, the ritual narrative begins with the affirmation of the local power, and only then establishes, again, through violence and veneration, that human beings are henceforth in control of that order. The wild power that is the deity-unknown, chaotic, and directionless-is reaffirmed, tamed, and reoriented, and what was once wilderness becomes human territory.

4 The sole ethnographic description of a sa chog rite was provided by Mary Van Dyke in 1997. ${ }^{2}$ To gain a general sense of the sa chog rite, I have compared four ritual manuals, supplemented by five addition texts that relate to it. Three of the sa chog texts date from the seventeenth-century, and the fourth is from the twentieth; together they provide examples from all four major sects of Tibetan Buddhism. Of the three seventeenth-century manuals only one is undated, that of the Kar ma bka' brgyud lama Karma chags med (1613-78). ${ }^{3}$ The next text was composed in 1642 by a 'Bri gung bka' brgyud pa patriarch, 'Bri gung rig 'dzin Chos kyi grags pa (1595/97-1659/62). ${ }^{4}$ The third is by the Fifth Dalai Lama's protégé and regent, sDe srid Sangs rgyas rgya mtsho (1653-1705), who wrote his manual some time between 1683 and $1685 .{ }^{5}$ The twentieth- 
century manual is by a Sa skya lama, bCo brgyad khri chen Thub bstan legs bshad rgya mtsho (b. 1920). ${ }^{6}$

In addition to the manuals I have examined five texts to supplement these. The first of these is a tenth-century Dunhuang text which closely resembles one segment of the ritual. ${ }^{7}$ The second is a twelfth-century text on burying a treasure vase, a step included in all the manuals, but described by none. This text is ascribed in the colophon as being the work of mNga' bdag Nyang ral Nyi ma 'od zer (1136-1204), the rNying ma pa treasure revealer (gter ston). ${ }^{8}$ The final three all give instruction for reckoning with the serpent in a context of laying a mandala in preparation for practicing tantric sādhana. The third is a commentary on the Guhyagarbha tantra by the fourteenth-century rNying ma lama Klong chen rab 'byams (1308-1364). ${ }^{9}$ The fourth is a section of the fifth chapter of Tsong kha pa's sNgags rim chen mo ("The great exposition on the stages of mantra"). ${ }^{10}$ The fifth is the Fundamentals of the Buddhist Tantras by a disciple of Tsong kha pa, mKhas grub rje dGe legs dpal bzang (1385-1438). ${ }^{11}$

6 The authors of the manuals cite a variety of canonical sources in their presentation of the rite. Karma chags med tells us that he has drawn upon a Kriyāyoga tantra and a text he refers to as the dGongs 'dus, which is likely the root Anuyoga Tantra, the dGongs pa 'dus pa'i mdo (SCMB, p. 95.2). Chos kyi grags pa references the Kālacakra, but otherwise refers only to multiple traditions of old and new translations of the secret mantra (SBLP1, p. 129; SBLP2, p. 99.6; SBLP3, p. 477). Sangs rgyas rgya mtsho writes: "Moreover, the methods set forth for examining the serpent in the Kriyā Tantra Susiddhikāra, ${ }^{12} \mathrm{Vajra}$ Garland and the General Secret Tantra(gSang ba spyi) ${ }^{13}$ and so forth are not in accordance with each other" (VDP, p. 392.l).

7 Looking to the supplementary texts, the Dunhuang manuscript makes reference to Kriyā admonitions for determining a proper place for performing the Yogatantra sādhana; Klong chen pa is of course commenting on the Guhyagarbha tantra, and he cites several additional titles; the Sequence of Indestructible Activity (rDo rje las rim),${ }^{14}$ the Commentary on the Eight Volumes of Nectar(Bam brgyad kyi 'grel ba) ${ }^{15}$ and the Flash of Splendor(Ye shes nam glog). ${ }^{16}$ Tsong kha pa cites many texts, among them the Vajrad̄ākinitantra ${ }^{17}$ and Vibhūti. ${ }^{18}$ mKhas grub rje also makes reference to several tantras in his discussion of rites for the preparation of laying the mandala, including the Cakrasamvvara and Kālacakra tantras. ${ }^{19}$ Thus we can see a clear influence of Indian tantric literature on geomantic rites in the Tibetan tradition of the sa chog. By the seventeenth century, ritual specialists could turn to various Kriyā, Yoga, Mahāyoga, Anuttarayoga and possibly Anuyoga tantras, as well as canonical Indian and Tibet commentaries, for divergent scriptural basis for their presentations of the $s a$ chog rite. ${ }^{20}$

What follows is an amalgamation of the aforementioned texts. While each of the four ritual manuals contains some or all of the steps I lay out, none exists in quite the same form. Indeed, only one text even uses the term sa chog in its title, that of Karma chags med, the author who seems least concerned with the topic. My justification for this synthetic approach derives in part from Van Dyke's description of an execution of this rite-it seems clear that the participants either combined elements from various manuals or relied on oral tradition, an avenue of inquiry beyond the scope of this essay. ${ }^{21}$ No single text includes instructions for the entire ritual as described by Van Dyke; Sangs rgyas rgya mtsho, the only author to include a reference to each part, does not actually explain several procedures. However, drawing from all the manuals together 
with the supplementary texts, each step can be described and placed into a mosaic, resulting in a coherent ritual whole.

To illustrate the composite quality of the 1967 rite, it is useful to compare the procedure followed by the monks in Rikon with the instructions of the manuals. The sa chog ritual performed in Rikon, Switzerland in 1967 followed seven basic steps. First (1) the site was selected and preliminary rites were performed. Then (2) a grid was laid, (3) the figure of the serpent was drawn and the vital place ( $s a$ dmigs; see below) was ascertained, (4) deities were invited and offerings were made, (5) the digging occurred and (6) the hole was tested. Finally (7) the vase was buried. A final step (8) is included in Sangs rgyas rgya mtsho and Chos kyi grags pa but was not done at Rikon: the release of the god by erasing the figure and the grid.

Steps two through seven are given their fullest treatment in Chos kyi grags pa's and Sangs rgyas rgya mtsho's texts. In Karma chags med's text we have only steps four and five-the text consists almost entirely of several tantric visualization of buddhas and other gods who bestow blessings and assist the ritualist in vanquishing harmful spirits. The text alludes to a hole dug in the earth only when one has read halfway through the text, and the grid and the orientation of the serpent are mentioned only at the end of the text, after the colophon, as though a later editor unsatisfied with Karma chags med's instructions appended it. bCo brgyad khri chen includes steps one through three and five through seven. He evidently based his account on that of Sangs rgyas rgya mtsho, as several passages are identical to the Vaidūryadkar po..$^{22}$ All our manuals have in common laying the grid, drawing the serpent, digging in the vital spot, and making offerings. I take these to be the basic elements of a sa chog, for it is by drawing the serpent to the surface, its hand cupped to its ear, that communication with the god is made possible, and it is through the violence of the digging and the succor of the offerings that the serpent is tamed and the land is seized.

11 My presentation follows the sequence common to the Rikon performance, the VDP and SBLP. I will include the variant and supplement material from the Dunhuang manuscript, Nyang ral, Klong chen pa, Tsong kha pa and mKhas grub rje in the footnotes.

\section{Step One: Preliminaries}

Before the communication with the serpent can take place the ground on which the sa chog will be performed must be consecrated, and permission to use it requested from the goddess of the earth, with compensation for that use offered. In several forms these preliminary prayers are redundant with the main part of the sa chog, and reflects the composite character of the rite as a whole. As bCo brgyad khri chen explains, the step is necessary to take possession of the land from its human and non-human owners. ${ }^{23}$ This initial step fills the first folio side of Karma chags med's text. Following the line quoted at the opening of this article, in which Karma chags med asserts the need for a sa chog, he instructs that the ritualist should make preliminary offerings of sacrificial cake (gtor $\mathrm{ma}$ ) and then visualize himself as a deity:

The master instantly transforms himself into Guhyapāti or Padmākara ${ }^{24}$ and so forth, whichever tutelary deity (yi dam) is suitable. With a vajra in the right hand strike the ground with the right hand three times in conjunction with the following chant:Hüm ! I, such and such yi dam, 
By striking the earth with my right hand

The six kinds of sa gas tremble. ${ }^{25}$

Thereinis the golden-colored earth god

Holding a vase of liberation, the upper body exposed,

Overflowing with radiant smiles of delight.

Om! God of the earth come hither, come hither.

Brtan ma goddess come hither.

Similar to the vow made in the powerful presence

of the Lord of Sages of the past

As substitute for the soil I offer gtor $m a$ and libationsAnd I offer the seven types of offerings.

[Recite] from om prithvi devī saparivāra arghaṃ to śabda pratīccha pūja ho:Oṃ! As done by the Bhagavan in the past

I appeal to the lords of the earth: abandon this place.

I prostrate to the goddess of the earth,

the support of the Bhagavan.

Reciting in this way, the goddess of the earth smiles broadly and she says: "[I]

present this ground [to] you, [you may] do as you like" and she dissolves.

(SCMB, p. 90.1-6)

bCo brgyad khri chen (pp. 29-31) similarly likens the request for the land to the Buddha's conquest over Māra and the recognition by the goddess of his right to sit at Vajrāsana. ${ }^{26}$

Sangs rgyas rgya mtsho's treatment of this step is similar. The site is consecrated by the various deities of the surroundings to ensure that the site is made suitable. He instructs the ritualist to take in hand a sickle, an antelope horn and, "as in the instructions for a tortoise [divination]," ${ }^{27}$ offer incense made of several substances employed for expelling both spirits and bad health from a body(VDP, p. 391.1). ${ }^{28}$ The ritualist should place in the four directions of the site certain substances: in the east the five metals, in the west fire, in the south water, and in the north "yellow soil," and at the edges of the site kila (ritual daggers) are to be placed, made of the jawbone of an animal called a shug(mtshams su shug mgal skyer phur gzug). He is then instructed to recite the "elemental incantation" ('byung sngags) and to "utter magic spells" (dmod mo brjod) (VDP, p. 391.2). Then this prayer is offered:

Sugata, yi dam, assembly of gods who abide in space and time, guardians [of the] outer and inner mandala together with the protectors, the oath bound ones, the guardians of the directions, the native lords, the eight classes of divine nāga, the haughty spirits, earth lords and earth lords of the sacred places: [at the time of this] day, month, year, planets, stars and zodiac constellations; powerful divine serpents, may you all make this blessed good earth fortunate and prosperous. Bless the construction of the patron's castle, expand the activity of friends and defenders and prosperity; pacify the diverse demons of illness and harm.

This, Sangs rgyas rgya mtsho writes, "is the performance of the ritual to cleanse the hostile ground" (VDP, p. 391.5-6). Thus be it by supplication to the same earth goddess the Buddha appealed to at Vajrāsana or to a host of buddhas and other deities, the site on which the sa chog will occur is purified and readied for the ritual to commence.

\section{Step Two: Laying the Grid}

In order to locate the serpent and ensure proper communication, a chart of sorts is laid out at the site. None of the ritual manuals give instructions for the precise placement of 
the grid in relation to the structure to be built, but they do name the four sides after the cardinal directions, the astrological value of which will become apparent. ${ }^{29} \mathrm{Chos}$ kyi grags pa's offers precise instructions for the preliminary construction of the grid: First the east-west axial line is laid. The middle of the line (and thus the center of the future square) is located, and the tips of the line are marked. Following that, one draws the north-south line so that it intersects with the east-west line at its center, making a cross. Then, lightly tracing the outer edge of the grid based on the extent of the two brahmā lines (here both axial lines are called "brahmā", the term used for the vertical axial line of a mandala), the four corners, named "fire," "demoness," "wind" and "power" (me srin rlung dbang) ${ }^{30}$ are marked, and finally the outer boundary of the grid is properly drawn (SBLP1, pp. 128-29; SBLP2, pp. 98.4-99.1; SBLP3, pp. 475.1-476.1).

Each side of the grid is then divided into the ten hand-lengths (cha chen or mtho) ${ }^{31}$ which are each further divided into nine thumb-widths (cha phran). One begins this process in the southeast corner named "fire," ${ }^{32}$ and continues in a clockwise direction. The marks are then connected to form the grid, so that the total number of squares in the grid equals eight thousand one hundred. The count of ninety squares on the four sides equals the total number of zodiac days (khyim zhag), or three hundred and sixty, each square along the edge standing for one day. Chos kyi grags pa explains that each cardinal direction/side of the grid represents one season of the year. The four squares at the ends of the two central axis stand for the fifteenth or sixteenth day of the second month of each season, and the four corners correspond to both the thirtieth day of the last month of each season, and the first day of the first month (SBLP1, p. 130; SBLP2, p. 100.2-100.3; SBLP3, p. 477. 4).

\section{Step Three: Drawing the Serpent}

The grid as drawn allows the lamas to determine the exact orientation of the serpent: depending on the date the ritual is performed, the tips of the serpent's head and tail will fall on particular squares along the edge of the grid. The serpent rotates with the seasons, its head moving one square to the right each day, and returning to the same spot year after year. However, not all the texts agree on the orientation of the figure. Indeed, Chos kyi grags pa complains that there are so many systems that one becomes exhausted in comparing them. Sangs rgyas rgya mtsho has it that in the winter the serpent's head is to the south, in spring to the west, in summer to the north, and in autumn to the east (VDP, p. 392.5). Chos kyi grags pa concurs, but first describes several alternate systems of orientation which are "like butter in water"33 (SBLP1, pp. 129-30; SBLP2, p. 100.1-100.2; SBLP3, p. 477.2). bCo brgyad khri chen follows the same orientation, but Karma chags med has the serpent facing north in spring, in summer to the east, in autumn to the south, and in winter to the west, a variation not mentioned by Chos kyi grags pa. ${ }^{34}$

19 The seasons of the Tibetan lunar calendar are as follows: winter is the eleventh, twelfth, and first months of the year; spring is the second, third and fourth months; summer is the fifth, sixth and seventh months; and autumn is the eighth, ninth and tenth months. At Rikon, where the monks nominally followed bCo brgyad khri chen's manual, because the performance took place on the 22nd day of the 6th lunar month, the head should have been placed on the 52nd square to the right from the northwest corner. However, at Rikon the serpent's head was oriented due north, on the central 
(forty-fifth) square, which according to the instructions in the manuals would have been incorrect by seven days and seven squares. ${ }^{35}$

When one has determined the orientation of the figure, the serpent is then drawn on the grid. ${ }^{36}$ Van Dyke, though she describes the serpent at Rikon, does not describe the process of drawing it, and thus we have no comparative to the texts. Chos kyi grags pa instructs the lama to first mark the center of the body, which falls half way between the head and the tail. The axis of the serpent's body follows that of the central north-south brahmā line of the grid and the width of the torso is two hand-lengths on either side. Chos kyi grags pa continues:

The hood is one hand-length. Similarly, the face is one hand-length. The heart center is one hand-length from there, and from the heart the navel is one handlength. From the navel, to the groin [gsang gnas; lit. "secret place"] is one handlength. The total number [of spans from the tip of the head to the groin] is five hand-lengths; the thumb-widths comes to forty five; this is the measurement of the upper torso. From the groin the tail emerges; from there to the tip of the tail is five hand-lengths. The crossing of the brahmā [lines], regardless of the date, invariably occurs at the intersection of the groin and the serpent's tail. The left side of the body is refered to as the "back" ('og) and the right side as the "front" (steng). The left hand is at the left ear. The right hand rests above the right waist holding a flaming wish fulfilling jewel.

(SBLP1, p. 131; SBLP2, pp. 101.5-102.1; SBLP3, p. 479)

21 Chos kyi grags pa also details the ornamentation, and likens the complexion of the serpent to the color of a lotus root. None of the texts describe the face, and the illustrations in the texts differ. bCo brgyad khri chen (1979) shows a bull's face (fig. 1). The VDP shows the face of a human (fig. 2) and Van Dyke (1997) reports that the figure drawn at Rikon was based on the illustration in the Vaidüryadkar po and therefore had a human face. The illustration in Meyer and Jest (1987) shows also the face of a human (fig. 3). 
Fig. 1 - The artist is Ven. Legdrub of Lumbini

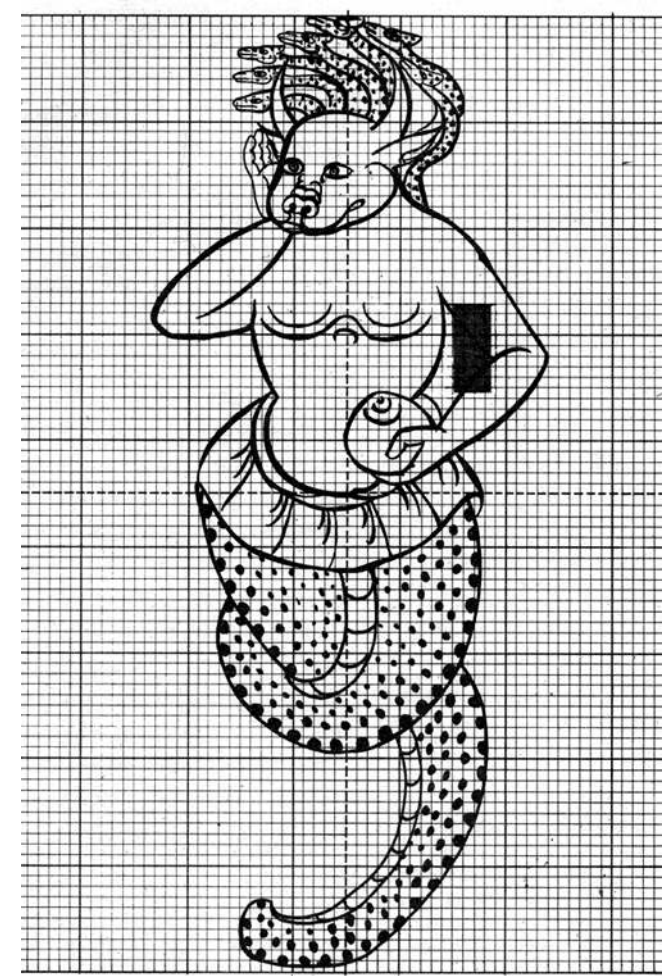

Note that the figure as depicted is reversed, based on the description in the text, but that the vital spot is in the proper place in relation to the grid

(bCo brgyad khri chen 1979, p. 31) 
Fig. 2 - The illustration as shown was produced by joining together the upper and lower halves of the image, from pages 392 and 393 (volume two) respectively

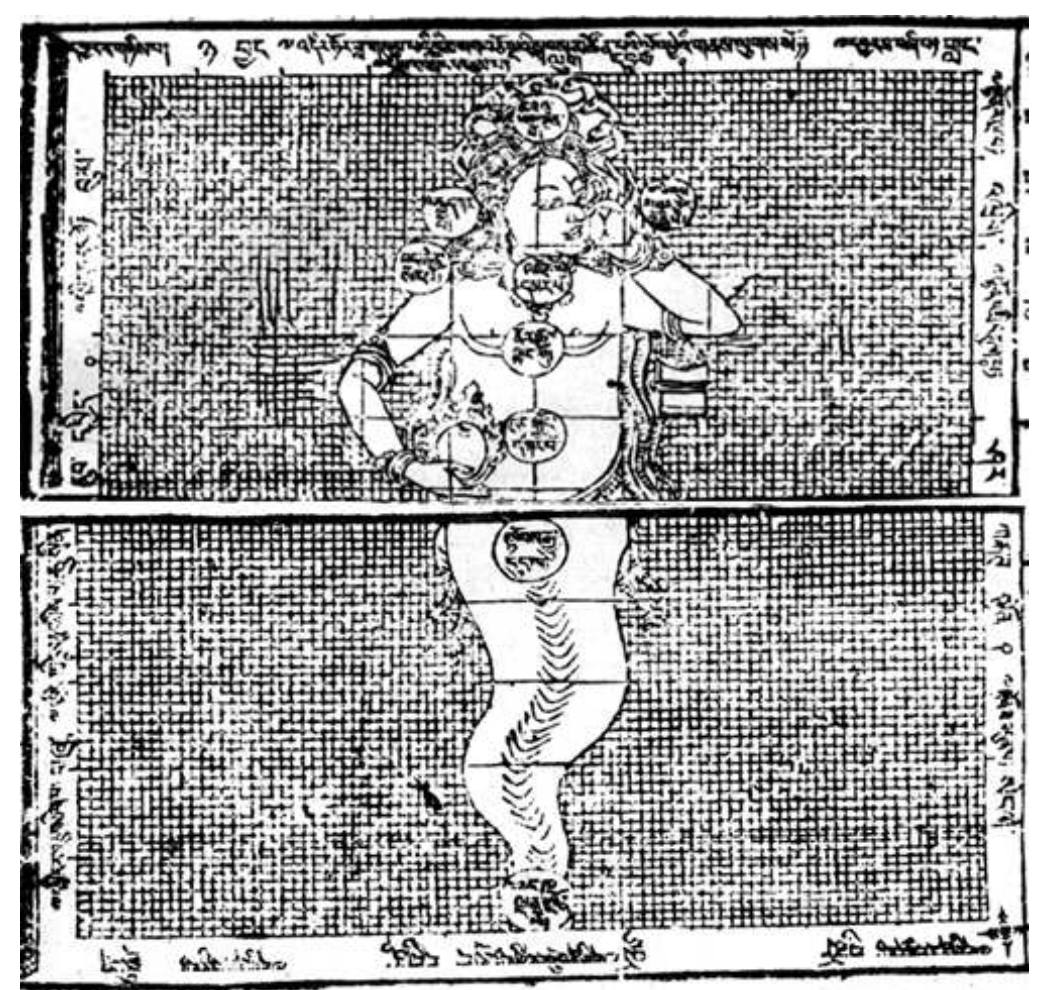

(VDP, pp. 392-393) 
Fig. 3 - The authors credit Meyer's informant, the Tibetan doctor Amchi Kunsang, with the illustration

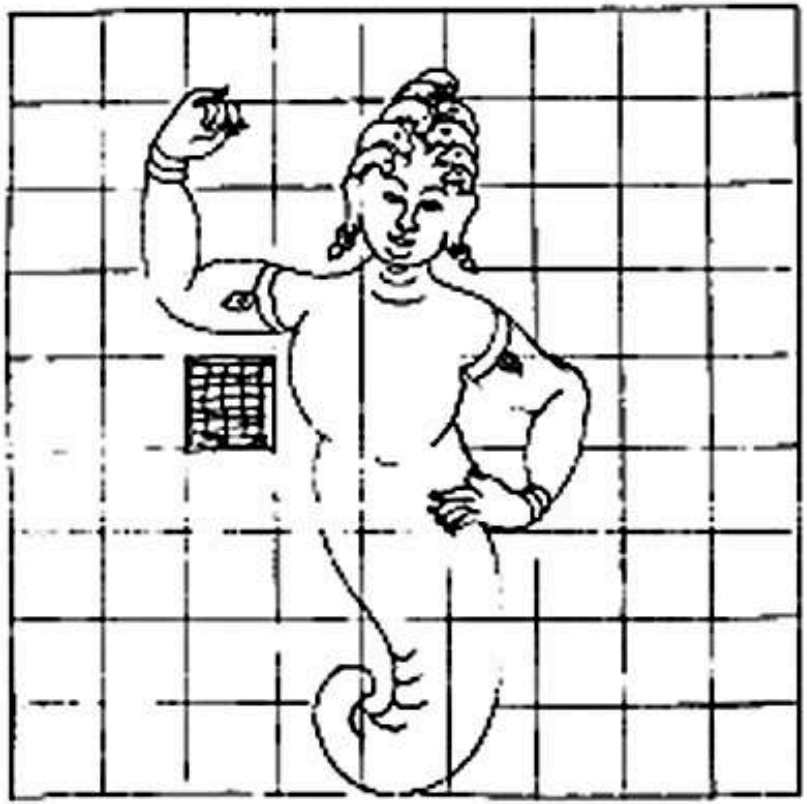

(Meyer and Jest 1987, p. 138) clear: de yang ngo bo mtha' yas dkar (VDP, p. 393.2-3). However, Vibhūti, as quoted in Tsong kha pa, has the line "Ananta himself, a body white and handsome" (mtha' yas bdag nyid dkar po mdzes pa'i sku), and a few lines below Tsong kha pa clarifies this: "the serpent is Ananta, white in color and handsome" (lto 'phye yang mtha' yas yin te mdog dkar la mdzes pa'o) (Tsong kha pa 1995, p. 183).

The serpent at Rikon, again in accordance with the Vaidūrya dkar po, was drawn with the Eight Great Nāga ${ }^{37}$ at specific locations on its body. Chos kyi grags pa also includes this detail, but Karma chags med and bCo brgyad khri chen (in text or illustration) do not. From the Vaidūrya dkar po:

Blue Kulika is at the tip of the tail; Karkotaka, the color of smoke, is at the groin; at the navel is white Sankhapāla; at the [right] shoulder is Mahāpadma of a yellow color; Green Vāsuki is at the heart center and Red Takșaka is at the neck. At the [right] ear is beautiful White Padma. Blue Ananta is at the top of the head.

(VDP, p. 393.3-4) po adds a detail not found elsewhere. The text describes the serpent to be "visually contemplating (mig tu bsgom) the Destroyer of Obstructers (bgegs mthar byed) ${ }^{39}$ (VDP, p. 393.4), represented by a ninth spot on the grid. This is placed in the illustration roughly five thumb-widths to the left of the figure's face and labeled accordingly. ${ }^{40}$

The crucial issue in drawing the serpent is to determine the location of its "vital place" (sa dmigs), ${ }^{41}$ the spot in which the digging, symbolic stabbing, will occur. Chos kyi grags pa gives two possible systems for locating this: 
Measure from the top of the central line of the body running down twenty-seven thumb-widths. Then from there measure down eighteen thumb-widths. From the midpoint of [forty-five thumb-widths down from the top] count nine thumb-widths from the "front" [that is, to the right of the center line]; the center of those [meaning four and one half thumb-widths from the central north-south line] is said to be the vital place. Alternately, having measured a line twenty-seven thumbwidths from the top, make a line of nine [thumb-widths] below that. Straight ahead from that measure fourteen and a half thumb-widths from the "back" and five and a half from the "front." The midpoint between those is explained to be the vital place. Thus there are two systems for [determining] the vital spot. Of the two, I think the later is correct, since it is below the armpit.(SBLP3, pp. 479.6-480.3)

26

Sangs rgyas rgya mtsho describes it as follows:

[Regarding] the manner of determining the vital place of accomplishment, for example, in the middle month of autumn, which is the center [square] on the eastern side, at that time the head is to the east and the tail is to the west. From the eastern side of the grid cast down three hand-lengths, the twenty-seven thumbwidths of the hood, face and heart area. Below this, casting fourteen and a half thumb-widths from the brahmā line to the north, in the "back", in front of that is the vital place: it is nine and a half thumb-widths from east to west [i.e. top to bottom], and five and a half from north to south]. This is the site for taking up the particular accomplishment. Otherwise, there are a few particular dissimilarities, which are explained in the chapter on the fruition.

(VDP, pp. 392.6-393.2)

These dissimilarities are presumably alternate systems of locating the vital spot. bCo brgyad khri chen's instructions are identical to Sangs rgyas rgya mtsho's. ${ }^{42}$ Instructions are not given by Karma chags med.

\section{Step Four: Offerings and Prayers to the Gods}

The ritual manuals all differ regarding the point at which this step ought to be performed and how. Karma chags med (SCMB, p. 91.1-6) has the ritualist supplicate and make offerings to various deities immediately after the invocation of the earth goddess and before a lengthy purification of the site. Sangs rgyas rgya mtsho (VDP, p. 393.2) includes only a single line on the issue of offering and supplication: "One should arrange the offering of the three whites, the three sweets, the nagga ritual cakes, and so forth and [perform] the offerings and praises." This comes in between the measurements for locating the vital place and the instructions on digging. ${ }^{43}$

My justification for placing this step here derives also from Van Dyke, who describes a lengthy feast offering at this juncture in the ritual: First offerings and water were arranged on a table beside the serpent. Then the Buddha, dharma, and sangha were supplicated, the site was declared to be a pure land, and the deities were invited to come to the feast. The gods were then bathed by the water and the seven-fold supplication was performed: prostration, offering, confession of faults, praise and rejoicing, request to turn the wheel of dharma and for the buddhas and bodhisattvas to remain in the world, and dedication (Van Dyke 1997, pp. 197-99). ${ }^{44}$ 


\section{Step Five: Taking the Attainment}

Having called forth the serpent and located the vital place, the critical moment in the sa chog ritual occurs. By digging in the vital place, the serpent is forced into submission and cedes the land to the supplicants. It is clear from Karma chags med, Chos kyi grags pa, Sangs rgyas rgya mtsho and bCo brgyad khri chen that the serpent does not surrender its authority of its own free will. All four of our manuals instruct the ritualist to assume wrathful guise and subjugate the earth, digging in the vital place not simply to test the soil and bury the treasure vase (the subsequent two steps) but to terrorize the serpent and force him to submit to human authority. ${ }^{45}$

Following his lengthy invocation to the deities, Karma chags med writes: "Then the master rises, twirling a kila, and instantaneously [takes the form] of Mahesvara Hayafriva, his lower body like a molar worn down in sleep [?], his complexion scarlet red, twirling a kila in his hand. Contemplating the subjugation of all the demons of the earth and spirits in hell and Vajrāsana he recites: hümpūmp̣a ha phem phem seven times, looking in the ten directions and twirling thekila" (SCMB, pp. 91.6-92.2). The master then proclaims the "wrathful mantra for subduing the soil" (sa 'dul drag sngags), by which the soil is subjugated (des sa' dul ba'o). ${ }^{46}$

2 Sangs rgyas rgya mtsho continues from the identification of the vital place to the layout of the eight nagga across the serpent's body and then immediately to the digging. Here the digging is called "taking the attainment" (dngos grub blang ba) and involves literally stabbing the earth with a pickax. Right after the statement that the serpent is looking at the Destroyer of Obstructers, the VDP continues: "The tantric geomancer himself visualizes [himself as] the Destroyer of Obstructers and wields a golden pickax marked with a five-pointed vajra with the right hand above and the left below, and facing east, digs five scoops: in the center, to the east, south, west, and north. Some also say that one should dig in a leftward direction. This is the place of attainment" ${ }^{47}$ (VDP, p. 393.4-5).

3 Chos kyi grags pa gives similar instructions: "Then the master, the Destroyer of Obstructers, infused with confidence, takes up a vajra-marked pickax, his left hand below and his right hand above. Before the master is the serpent's head, behind him its tail; scatter the four scoops of soil dug from vital place beyond the fire corner. Because the fifth scoop is the earth attainment, it should be thrown into a vessel" (SBLP1, p. 134; SBLP2, p. 105.1-2; SBLP3, p. 483.1-3). bCo brgyad khri chen (1979, p. 33) likewise states that subjugation rites are part of the sa chog, but he does not indicate at which point they should occur. He mentions them after the instructions for burying the vase. ${ }^{48}$

\section{Step Six: Testing the Soil}

The testing of the soil is in two sections: the examination of the attributes of the soil and the use of the hole to test fecundity of the soil itself. ${ }^{49}$ Sangs rgyas rgya mtsho and Chos kyi grags pa instruct that the signs be read from the soil dug from the vital place, and this is confirmed by bco brgyad khri chen, who, although he gives his instructions for the soil test prior to his instructions for laying the grid, writes that the test should be done in the hole dug in the center of the vital place (1979, p. 30). He does not, however, include an examination of the hole itself. 

vase at this point in their instructions, which suggests that instructions for such a ceremony were not necessary, as this step likely would have been familiar to most ritual masters. ${ }^{57}$ With soil from the last scoop, Chos kyi grags pa instructs the ritualist to "feign ${ }^{58}$ to take in hand the treasure vase, insert it well [into the ground] and cover it with soil." ${ }^{59}$ In the Vaidürya dkar po, following the line in which the master determines that the klu are afraid, Sangs rgyas rgya mtsho continues: "In order to alleviate [the serpent's] torment bury the vase treasure and offer gtor." ${ }^{60}$ bCo brgyad khri chen simply writes that one should remove defects from hole, insert the treasure, and solidly cover it. ${ }^{61}$

\section{Step Eight: Releasing the Serpent}

As stated above, this step did not occur at Rikon. Instead of erasing the grid like a troupe of touring monks brushing away a sand mandala, the lamas at Rikon wanted to preserve the diagram for the enjoyment of visitors. Van Dyke reports that the grid was protected throughout construction by slabs of concrete surrounded by masonry (1997, 
p. 203). She does not relate what happened to the grid after that, whether it was drowned in poured concrete or if it exists still, covered by a raised first floor. Both Sangs rgyas rgya mtsho and Chos kyi grags pa, however, are explicit in their instructions that the grid and serpent be erased. Following the instructions to offer a vase, Sangs rgyas rgya mtsho then writes: "Request [the serpent] to depart and request the fulfillment of prayers. One should utter the benediction [and] obliterate the lines and forms of the soil of the attainment by covering it with other soil [to the point that they are] unobservable" (VDP, p. 394.3). Chos kyi grags pa gives similar instructions: "Having performed offerings and praises to the earth lord, ask his forgiveness and contemplate him, together with his retinue, dissolving joyously into the foundational earth. The form and lines and so forth should not [remain] visible. ${ }^{62}$ Cast the offering gtor ma beyond the edge of the fire [and other corners of the grid]" (SBLP1, p. 135; SBLP2, p. 106.1-2; SBLP3, p. 484.3-4). Neither Karma chags med nor bCo brgyad khri chen describe the release of the serpent.

\section{Postscript: The Warnings}

Van Dyke's sources led her to understand that without correct calculations "no offering can be made effectively" to the serpent and "no blessing will remain with the building" (1997, p. 195). She quotes Wangmo (1985, p. 110) in saying that "if one digs in the wrong place by mistake this will have a bad effect on the occupants of the house." Compared with the other manuals, these are understatements. Chos kyi grags pa's phrasing is the most dire. His first warning comes after the instructions for laying the grid. He writes:

If one recklessly approximates the date in ignorance of the measurement of the body and the place and the attainment, ${ }^{63}$ this will be very serious; one will come down with the five poisons of sight, touch, thought, breath and so forth. [Were one to dig] on the head, back, tail, arm, face, buttocks and so forth of the nāga, the king of all the earth lords, with his retinue of gods and demons, Rahū, the eight classes [of gods and demons]: when facing an army one's general will be killed; if a mandala is drawn, the master will pass away; if one takes a wife, she will die; if one confronts magic [one] will suffer the spells; if one [practices in] a charnel ground, an astrologer will die; if one offers a banquet plagues will arise; if one stages performances harm will befall everyone; if one attempts to cure an illness the lifeforce will be stolen; if one builds a house it will become a charnel ground. Thus whatever is done, it is said that obstacles or illness will befall you: if one erects a dharma-throne the teachings will decline; if one performs a bleeding or moxibustion the cure will be reversed and the life-force will be destroyed. Therefore it is important to be careful in this matter.(SBLP1, p.130; SBLP2, pp. 100.4-101.2; SBLP3, pp. 477.5-478.4)

Later in the text he again warns on the results of improper execution of the rite:

If one digs elsewhere than in [the] vital [place, and digs in] the nine-fold place, ${ }^{64}$ one's father, mother, son, relative, wife, daughter, and companion will die. If one chooses the back, one will die oneself or be expelled from the place. If the tail is selected, horses, cows, oxen, and so forth, the four-legged [beasts] will be destroyed and one's own strength will also diminish.

(SBLP1, pp. 135; SBLP2, p. 105.5-6; SBLP3, pp. 483.6-484.2)

This second warning is only slightly different in the Sangs rgyas rgya mtsho (VDP, p. 394.4-5). For warnings bCo brgyad khri chen (1979, p. 33), simply writes "If one is not diligent in analyzing, investigating, seizing, and subduing the land, no matter how one proceeds, there will be obstructions, obscurations and dangers." 

included numerous instances in which the Rikon lamas did not follow proper ritual procedures as she was led to understand them. Nor, she states, were the Tibetans "unduly worried" by their deviations (1997, p. 186). As Van Dyke reports, they did not locate the grid where the main shrine room would stand nor orient it along the cardinal directions; they did not place the head of the serpent in the proper square according to the date of the performance (which in any case was changed at the last minute to accommodate the film crew) but simply oriented it to the center of the grid (Van Dyke 1997, p. 194). If we consider that the serpent is present whether drawn or not, rotating with the seasons, then digging beside an improperly located figure could result in digging in the serpent's body rather than right beside it, with all its accompanying dire consequences. Nor did the monks bury the vases in the vital place, inserting them instead in a hole outside the grid altogether, two days after the sa chog itself was performed. And not only did they not erase the figure and the lines of the grid, but following the concluding benediction the drawings were touched up, and the image was then protected for posterity by a concrete slab.

The monks at Rikon did not seem to take the warnings against improper performance of the rite terribly seriously. Indeed, given the variation in the texts and the multiplicity of orientations for the serpent, they would have reason to feel confident that the power was not in the details. Faced with such variety, a ritualist can either chose one text to follow to the letter, or can draw from several and perform an essentialized rite, all according to where he stands in a given tradition. The manual authors would have numerous reasons for promoting their own systems of calculations, knowing as they did that other systems were out there and available.

Reading the warnings as advertisements for the rite rather than a given presentation's specifics, however, affirms the importance of the rite itself. Common to all the texts' warnings is the basic assertion that the rite be performed; that prior to occupying a piece of ground it be properly landscaped, publicly inserted into the socio-geographical order. Van Dyke and others are correct in pointing out that the sa chog is a means of taking possession of land. All the same, what they seem to overlook is the fundamental violence of the rite. It is not a peaceful transfer of a deed in which land is willingly bought and sold. The serpent's land is confiscated, and this is achieved through violent means. The treasure offered to the deity is a payment, but, as Sangs rgyas rgya mtsho explained, it is given in order to alleviate the serpent's torment. This torment is the fear caused by digging in the prescribed spot, a symbolic stabbing wrapped in a wrathful subjugation narrative. The serpent's fear must be taken as a desired result of the sa chog, a necessary ingredient of the ritual. The vital place is located in order to maximize the violence of the rite while ensuring that the fecundity of the soil is not damaged-surely that is the worry expressed by the warnings. For why, if the vital place is located in order to avoid harming the serpent, as Meyer and Jest (1987, p. 154) understand it, would the serpent need be afraid? If there was truly a desire to avoid worrying the serpent, the digging could take place well outside the grid altogether. The monks at Rikon, in all their improvisation, still stabbed the vital spot.

Digging in the soil is understood in Tibet to be a violent act. Buddhism of course warns against the harm done to insects by plowing and tilling soil. ${ }^{55}$ But Tibetans also understand that the simple act of breaking soil and taking possession of land will injure earth deities. Stein (1972, pp. 243-246) understood this to be a non-Buddhist element of 
Tibetan religion, and whether or not this was the case, Buddhist rites brought in from India, China and elsewhere reinforce the belief. Narratives of violent ritual conversion are snuggly woven into the myths of Buddhism's introduction into Tibet. Padmasambhava famously converted the autochthonous Tibetan deities in the eighth century (though much of his activity is likely to have been a later biographical invention) and later lamas continued the job, subjugating local spirits in the course of opening hidden valleys and/or extracting treasure texts. Such subjugation narratives take as their archetype the Buddha's defeat of Rudra, which is played out repeatedly in the landscaping narratives of the great battle between Cakra-sa mvara and Bhairava. ${ }^{66}$ All this seems to be at play in the sa chog, when the ritualist leaps from his seat twirling a kila, intent on thrusting it into the ground to tame the lord of the soil.

Equally important in the sa chog rite is the stabilization of the earth. In this aspect of the rite the second function of the kila is apparent. Stein (1972, pp. 202-212) held that the phur pa (the standard Tibetan translation for kila) was used in non-Buddhist Tibet to both stabilize the earth and prop up the heavens. Non-Buddhist or not, this dual use of the kila surely originated in India, as well documented in Mayer (1991). Boord (1993, p. 39) also relates this aspect of the kila to early Vedic myth in which Indra vanquished Vrrda, and, as seen above, this function of the kila in the sa chog is affirmed by bCo brgyad khri chen.

48 Not all Tibetan landscaping rituals activities are necessarily violent. Much about the $s a$ chog is reminiscent of other rites described in scholarship on Tibetan sacred geography. Scholars have described how Tibetan pilgrimage serves to mark sacred space, contain its wild power through circumambulation, and take possession of its power by subjugating its gods, naming, and otherwise landscaping the physical features of the environment through narrative description. ${ }^{67}$ The demarcation of the grid similarly calls to mind Charles Ramble's discussion of a harvest festival in which sacred texts are carried around the perimeter of cultivated fields in order to protect them from external harm (Ramble 1996, p. 145). Ramble's example illustrates how Tibetans have the means not only to contain wilderness in a site but also exclude it from a particular place.

The Tibetan sa chog ritual as I have read it is an amalgam of all of these goals. It subjugates wild spirits of the soil, it stabilizes and contains the land, it simultaneously venerates and seeks to dominate the power of the earth, and it organizes space for human occupation and use. The serpent, contained within a grid, has its hand to its ear in order to listen to the commands of the invaders of the land, the self-styled Destroyer of Obstructers who, by inserting himself into the grid alongside the serpent, has staked his claim to the land. The serpent is subjugated through violent threats and acts that terrorize it, and, newly dominated by the human newcomers, given treasure as payment in order to ameliorate its suffering. Like the generalized earth spirits Hubert and Mauss describe in the passage that opens this essay, and like Rudra himself, the serpent is symbolically killed and resuscitated, vanquished, revived and venerated. This is done because the serpent is not simply the owner who is dispossessed of the land, but is the land itself. It is the land in all its potential. Its power is the soil's fecundity. The serpent, wild and untamed, has no obligation to channel that potential into beneficial results, no reason not to unleash the danger of death and disease that the ritual manuals make clear he has sway over. But a subjugated deity is bound by oath to place his power in service to the human community. Thus when the serpent departs, just as a 
deity departs from a feast offering, he does not actually leave. The serpent instead has ceded his authority over the land to the ritualist, and his space has become human space.

\section{BIBLIOGRAPHY}

\section{Abbreviations}

bCobrgyadkhrichen: bCobrgyadkhrichen Thubbstanlegsbshadrgyamtsho.

Tsongkhapa: Tsongkhapa Blobzanggragspa.

BGB: Nyangral Nyima 'odzer.

SBLP: 'Brigungrig 'dzinchoskyigragpa.

SCMB: Karmachagsmed.

VDP: Sangsrgyasrgyamtsho.

\section{Tibetan Sources}

Thams cad bdud rtsi lnga'i rang bzhin dngos grub chen po nye ba'i snying po'i mchog bdud rtsi mchog gi lung bam po brgyad pa'i mchog 1982 In rNying ma'i rgyud 'bum (mTshams brag edition) (Thimphu, National library, Royal Government of Bhutan), vol. 34 (ngi), pp. 2-98.

Bod rgya tshig mdzod chen mo

1993 (Beijing, Mi rigs dpe skrun khang), 3293 p.

IOL Tib J 447

Untitled commentary to the Āryatattvasamgraha-sādhanopāyika, a sadhana for the Sarvatathāgatatattvasamgraha, the main Yoga tantra.

Karma chags med (abb. SCMB)

1976 Sa chog mdor bsdus bya tshul gsal ba bzhugs so, in Rin-chen gter mdzod chen mo, edited by 'Jam mgon kong sprul Blo gros mtha' yas (Paro, Ngodrup and Sherab Drimay), vol. 66 (te), pp. 89-95.

Klong chen pa

1999 Dpal gsang ba'i snying po de kho na nyid nges pa'i rgyud kyi 'grel pa phyogs bcu'i mun pa thams cad rnam par sel ba, in rNying ma bka' ma shin to rgyas pa, edited by Ka..h thog mkhan po 'Jam dbyangs (Chengdu, Kah thog mkhan po 'Jam dbyangs), vol. 68, pp. 5-683.

Nyang ral Nyi ma 'od zer (abb. BGB)

1976 Bkra shis gter gyi bum pa bzang po'i rten 'brel gyi man ngag bzhugs so, in Rin chen gter mdzod chen mo, edited by 'Jam mgon kong sprul Blo gros mtha' yas (Paro, Ngodrup and Sherab Drimay), vol. $76(n u)$, pp. 37-40. 
bCo brgyad khri chen Thub bstan legs bshad rgya mtsho (abb. bCo brgyad khri chen) 1979 Dgon gnas 'debs yul sa dpyad dang sa brtag bzung gtsug lag khang rgyag stang, translated by David Paul Jackson (Gateway to the Temple: Manual of Tibetan Monastic Customs, Art, Building and Celebration) (Kathmandu, Ratna Pustak Bhandar), pp. 29-33.

'Jam mgon kong sprul yon tan rgya mtsho.

1997 Kong sprul yon tan rgya mtsho'i rnam thar (Chengdu, Si khron mi rigs dpe skrun khang).

'Bri gung rig 'dzin Chos kyi grags pa (abb. SBLP)

1970 Sa bdag lto 'phye chen po brtags pa'i rab tu 'byed pa nyes pa kun sel, in The Design and Creation of Buddhist Icons (Paintings, Statues, Stupas and Mandalas), edited by Khams sprul Don brgyud nyi ma (Tashijong, India, The Sungrab Nyamso Gyunpel Parkang Tibetan Craft Community), pp. 128-136 [abb. SBLP1].

1976 Sa bdag lto 'phye chen po brtags pa'i rab tu 'byed pa nyes pa kun sel, in Rin chen gter mdzod chen mo, edited by 'Jam mgon kong sprul Blo gros mtha' yas (Paro, Ngodrup and Sherab Drimay), vol. 65 (te), pp. 97-107 [abb. SBLP2].

1999 Sa bdag lto 'phye chen po brtags pa'i rab tu 'byed pa nyes pa kun sel, in The Collected Works (gsun 'bum) of Kun-mkhyen Rig-pa 'dzin-pa Chen-po Chos kyi grags pa (Deradun, Drikung Kagyu Institute) [abb. SBLP3].

Tsong kha pa Blo bzang grags pa

1995 rGyal ba khyab bdag rdo rje 'chang chen po'i lam gyi rim pa gsang ba kun gyi gnad rnam par phye ba (Xining, mTsho sngon mi rigs dpe skrun khang).

Sangs rgyas rgya tsho (abb. VDP)

1972 Vaidūrya dkar po: Reproduced from a print from the Lhasa Blocks from the Collection of Burmiok Athing (New Delhi, T. Tsepal Taikhang), 2 vol.

\section{Western Sources}

Bacot, Jacques

1935 Le mariage chinois du roi tibétain Sron bcan sgam po (extrait du Mani bka' 'bum), in Mélanges chinois et bouddhiques (Bruxelles/Louvain, Imprimerie Orientaliste Marcel Istas), III, pp. 1-60.

Boord, Martin J.

1993 The Cult of the Deity Vajrakila according to the texts of the northern treasures tradition of Tibet (Byang-gter phur-ba) (Tring, U.K., Institute of Buddhist Studies).

Buffetrille, Katia

1994 The Halase-Maratika Caves (eastern Nepal). A sacred place claimed by both Hindus and Buddhists (Pondicherry, French Institute of Pondicherry) [Pondy Papers in Social Sciences, 16]. 1997 The Great Pilgrimage of A myes rma chen. Written tradition, living realities, in

A. MacDonald (éd.), Mandala and Landscape (New Delhi, D.K. Printworld), pp. 75-132.

1998 Reflections on pilgrimages to sacred mountains, lakes and caves, in A. McKay (éd.),

Pilgrimage in Tibet (Richmond, Surrey, Curzon), pp. 18-34.

1999 The Blue Lake of A-mdo and its island: Legends and pilgrimage guide, in T. Huber (éd.), Sacred Spaces and Powerful Places in Tibetan Cultures (Dharamsala, Library of Tibetan Works and Archives), pp. 105-124.

Cantwell, Catherine Mary

1989 An ethnographic account of the religious practice in a Tibetan Buddhist refugee monastery in Northern India. Ph.D. Dissertation (University of Kent). 
Cohen, Richard

1998 Nāga, Yakșinī, Buddha. Local deities and local Buddhism at Ajanta, History of Religions,

XXXVII, 4, pp. 360-400.

Daniel, E. Valentine

1984 Fluid Signs. Being a person the Tamil way (Berkeley, University of California Press).

Davidson, Ronald

1991 Reflections on the Mahesvara subjugation myth. Indic materials, Sa-skya apologetics, and the birth of Heruka, Journal of the International Association of Buddhist Studies, XIV, 2, pp. 197-233.

Dudjom rinpoche Jikdrel yeshe dorje

1991 The Nyingma School of Tibetan Buddhism. Its Fundamentals and History, translated by Gyurme Dorje and M. Kapstein (Boston, Wisdom Publications), I.

Epstein, Lawrence and Wenbin Peng

1994 Ganja and Murdo. The social construction of space at two pilgrimage sites in eastern Tibet, Tibet Journal, XIV, 3, pp. 21-45.

Gyatso, Janet

1987 Down with the Demoness. Reflections on a feminine ground in Tibet, Tibet Journal, XII, 4, pp. 38-53.

Gyurme Dorje

1987 The Guhyagarbhatantra and its 14 th century Tibetan commentary Phyogs bcu mun sel. Ph.D. Dissertation (SOAS, University of London).

2001 Tibetan Elemental Divination Paintings: Illuminated Manuscripts from the White Beryl of Sangs rgyas rgya mtsho with the Moonbeams Treatise of Lo-chen Dharma Srī, in association with Sam Fogg (London, John Eskenazi).

Gyurme Dorje, and Matthew Kapstein

1991 The Nyingma School of Tibetan Buddhism. Its Fundamentals and History (Boston, Wisdom Publications), II.

Huber, Toni

1990 Where exactly are Cāritra, Devikoța and Himavat? A sacred geography controversy and the development of Tantric Buddhist pilgrimage sites in Tibet, Kailash, XVI, 3-4, pp. 121-164. 1994a When what you see is not what you get. Remarks on the traditional Tibetan presentation of sacred geography, in G. Samuel, H. Gregor and E. Stutchbury (éd.), Tantra and Popular Religion in Tibet (New Delhi, International Academy of Indian Culture and Aditya Prakashan), pp. 39-53. $1994 \mathrm{~b}$ Putting the Gnas back into Gnas-Skor. Rethinking Tibetan Buddhist pilgrimage practice, Tibet Journal, XIV, 2, pp. 23-60.

1994c Why can't women climb Pure Crystal Mountain? Remarks on gender, ritual and space in Tibet, in Tibetan Studies. Proceedings of the 6th Seminar of the International Association for Tibetan Studies, Fagernes, 1992 (Oslo, Institute for Comparative Research in Human Culture), I, pp. 350-372. 1997a Ritual and politics in the eastern Himalaya. The staging of processions at Tsari, in S. G. Karmay and P. Sagant (éd.), Les Habitants du Toit du Monde (Nanterre, Société d'ethnologie), pp. 221-260.

1997b A guide to the La-Phyi Mandala. History, landscape and ritual in south-western Tibet, in A. MacDonald (éd.), Mandala and Landscape (New Delhi, D.K. Printworld), pp. 233-286.

1999 The Cult of Pure Crystal Mountain. Popular pilgrimage and visionary landscape in southeast Tibet (New York, Oxford University Press). 
Hubert, Henri and Marcel Mauss

1964 Sacrifice. Its nature and functions, translated by W. D. Halls (Chicago, University of Chicago

Press)].

Kapstein, Matthew

1992 Samantabhadra and Rudra. Innate enlightenment and radical evil in Tibetan Rnying-ma-pa Buddhism, in F. Reynolds and D. Tracy (éd.), Discourse and Practice (Albany, State University of New York Press), pp. 51-82.

1998 A pilgrimage of rebirth reborn, in M. Goldstein and M. Kapstein (éd.), Buddhism in Contemporary Tibet. Religious revival and cultural identity (Berkeley, University of California Press), pp. 95-119.

Kohn, Richard J.

1997 A prayer to the God of the Plain, in D. S. Lopez Jr. (éd.), Religions of Tibet in Practice

(Princeton, Princeton University Press), pp. 387-394.

Kramrisch, Stella

1946 The Hindu Temple (Calcutta, The University of Calcutta).

Lindegger-Stauffer, Peter

1971 Das Klösterliche Tibet-Institute in Rikon/Zürich, Asiatische Studien, 25, pp. 377-88.

Ling, Trevor

1997 Buddhism and the Mythology of Evil (Oxford, Oneworld).

MacDonald, Alexander

1990 Hindu-isation, Buddha-isation, then Lama-isation or: what happened at La-phyi?, in

T. Skorupski (éd.), Indo-Tibetan Studies. Papers in Honour and Appreciation of Professor David

L. Snellgrove's Contribution to Indo-Tibetan Studies (Tring, U.K., Institute of Buddhist Studies), pp. 199-208.

Mayer, Robert

1991 Observations on the Tibetan Phur-pa and the Indian Kila, in T. Skorupski (éd.), The Buddhist Forum (London, School of Oriental and African Studies, University of London), II, pp. 163-192. 1996 A Scripture of the Ancient Tantra Collection. The Phur-pa bcu-gnyis (Oxford, Kiscadale Publications).

1998 The figure of Mahesvara/Rudra in the rNying-ma-pa Tantric tradition, Journal of the International Association of Buddhist Studies, XXI, 2, pp. 271-310.

Meyer, Fernand et Corneille Jest

1987 Milieux, matériaux et techniques, in G. Béguin and P. Mortari Vergara (éd.), Demeures des Hommes, Sanctuaires des Dieux (Rome, Université de Rome), pp. 146-167.

Miller, Robert James

1998 The Supine Demoness (Srin mo) and the consolidation of Empire, Tibet Journal, XXIII, 3, pp. 3-22.

mKhas grub rje dGe legs dpal bzang po

1968 Mkhas grub rje's Fundamentals of the Buddhist Tantras. Rgyud sde sphyi'i rnam par gzhag pa rgyas par brjod, translated by Ferdinand Lessing and Alex Wayman (The Hague, Mouton).

Nebesky-Wojkowitz, René de

[1975] 1993 Oracles and Demons. The cult and iconography of the Tibetan protective deities (Kathmandu, Book Faith India). 
Parfionovich, Yuri, Fernand Meyer and Gyurme Dorje (éd.)

1992 Tibetan Medical Paintings; Illustrations to the Blue Beryl Treatise of Sangye Gyamtso (1653-1705)

(New York, Harry Adams).

Ramble, Charles

1996 Patterns of Places, in A.-M. Blondeau and E. Steinkellner (éd.), Reflections of the Mountain:

Essays on the History and Social Meaning of the Mountain Cult in Tibet and the Himalaya (Vienna, Verlag der Österreichischen Akademie der Wissenschaften), pp. 141-153.

Schrempf, Mona

1999 Taming the earth, controlling the cosmos. Transformation of space in Tibetan Buddhist and Bon-po ritual dance, in T. Huber (éd.), Sacred Spaces and Powerful Places in Tibetan Culture

(Dharamsala, Library of Tibetan Works and Archives), pp. 198-224.

van Spengen, Wim

1998 On the geographical and material contextuality of Tibetan pilgrimage, in A. McKay (éd.),

Pilgrimage in Tibet (Richmond, Surrey, Curzon), pp. 35-51.

Sperling, Elliot

1976 Some observations on the marriage of the Tibetan king Srong-btsan sgam-po to the Chinese princess Wen Cheng, The Tibet Society Bulletin, 10, pp. 29-47.

Stein, Rolf A.

1972 Tibetan Civilization, translated by J. E. Stapleton Driver (Stanford, Stanford University Press). 1995 La soumission de Rudra et autres contes tantriques, Journal Asiatique, CCLXXXIII, 1, pp. 121-160.

Steinmann, Brigitte

1998 The opening of the sBas Yul 'Bras mo'i gshongs according to the Chronicals of the Rulers of Sikkim. Pilgrimage as a metaphorical model of the submission of foreign populations, in A. McKay (éd.), Pilgrimage in Tibet (Richmond, Surrey, Curzon), pp. 117-142.

Thanissaro Bhikkhu

1994 The Buddhist Monastic Code, Volume One. The Patimokkha training rules translated and explained (Valley Center, CA, Metta Forest Monastery).

Van Dyke, Mary

1997 Grids and Serpents. A Tibetan foundation ritual in Switzerland, in F. J. Korom (éd.),

Constructing Tibetan Culture. Contemporary Perspectives (Quebec, World Heritage Press), pp. 178-227.

Wangdu, Pasang

2002 King Srong btsan sgam po according to the Dba' bzhed. Remarks on the introduction of Buddhism into Tibet and on the greatest of the Tibetan royal ancestors, in $\mathrm{K}$. Buffetrille and H. Diemberger (éd.), Territory and Identity in Tibet and the Himalayas (Leiden, Brill), pp. 17-33.

Wangmo, Chime

1985 Rituals of Bhutanese house construction, in B. Nimri Aziz and M. Kapstein (éd.), Soundings in Tibetan Civilization (New Delhi, Manohar), pp. 107-114.

\section{NOTES}

1. Sa chog mdor bsdus bya tshul gsal ba ("An elucidation of the means for practicing an abridged sa chog," henceforth SCMB), in volume 65 (te) of lDil mgo mkhyen brtse's edition of the Rin chen gter mdzod, p. 90). Another author lists places that do not require a sa chog: "The places that do not 
need a sa chog [include] a sage's abode, a cattle pen, a cave, the peak of a mountain, wherever the ground is solid, an empty house, a stone slab, beside a stūpa, an island in a waterfall, and the ground at the shores of lakes. One need not exert oneself in purifying and analyzing the placehigh or low and so forth, there are few concerns" (VDP, p. 394.4-5).

lTo 'phye, or "serpent" (literally "breast-goer") is the general term used in the sa chog manuals consulted for this paper.The texts occasionally use the term klu, an indigenous Tibetan term used to translated the Sanskrit nāga (often rendered as "dragon"), but not in reference to the serpent deity that is the focus of the ritual. That there is a conflationin the texts of the two terms, lto 'phye and klu, is made evident by the location of the eight nāgarāja of Indian mythology at specific places onto the serpent's body, and the further identification of the serpent with Ananta, one of the nāgarāja (see below). For an informative discussion of its worship in an Indian context, see Cohen (1998).

2. Van Dyke's description is of a sa chog performance that took place on July 28th, 1967, the 22nd day of 6th lunar month, in Rikon, Switzerland. Her narrative is based on two films made by a crew from Göttingen, Germany, the commentary to those films, and published accounts by and personal communications with one of the sponsors of the Tibetan community there. In addition she relied on scholarship on the sa chog and relating topics, including Meyer and Jest, Lindegger, bCo brgyad khri chen in translation, and Wangmo. She also references Ph.D. dissertations by Cantwell and Boord (which has since been published as Boord 1993). I did not consult the films nor their commentary.

Van Dyke explains that the films were made at the Tibetans' behest, and that the ritual was somewhat organized around the filming. Originally the Tibetans intended to perform a rehearsal the 28th, and the real ritual was to take place on the 29th. Instead they decided to perform the sa chog on the 28th, and film the actual ritual. Van Dyke was given no explanation for the change, and remarks that the 29th was "presumably chosen for astrological auspiciousness." In addition to the exigencies of the film, certain elements of the ritual were altered in order to honor local dignitaries invited to the site.

3. Sa chog mdor bsdus bya tshul gsal ba ("An elucidation of the means for practicing an abridged sa chog," henceforth SCMB). Karma chags med, who was also a master in the rNying ma lineage, is said to have been the reincarnation of both Padmasambhava's disciple Cog ro Klu'i rgyal mtshan, one of Padmasambhava's twenty-five disciples and an important early translator, as well as a reincarnation of the Eighth Karmapa, Mi bskyod rdo. The Rin chen gter mdzod ("Precious Treasury of Revealed Teachings") is a collection of revealed teachings (gter ma) compiled by the the bKa' brgyud lama 'Jam mgon kong sprul Yon tan rgya mtsho (1813-1899).

4. Sa bdag lto 'phye chen po brtags pa'i rab tu 'byed pa nyes pa kun sel ("A full investigation into the great serpent earth lord [or]A complete clarification of error," henceforth SBLP).I was able to locate three editions of this text. The first is found in The Design and Creation of Buddhist Icons (Paintings, Statues, Stupas and Mandalas), compiled in 1970 by the members of the Sungrab Nyamso Gyunpel Parkang Tibetan Craft Community in Tashijong, India. The second is in volume 65 (te) of lDil mgo mKhyen brtse's edition of the Rin chen gter mdzod. The third is found in the 1999 edition of Chos kyi grags pa's collected works. This third edition is the clearest by far, though here as well there are what appear to be scribal errors. The three will be referenced in that order as SBLP1, SBLP2 and SBLP3, with the page numbers from the differing editions separated with semicolons. Chos kyi grags pa, the twenty first throne holder (gdan rabs) of 'Bri gung, was a disciple of the great treasure revealer Rig 'dzin 'Ja' tshon snying po and was renowned in his day for his exposition of the 'Bri gung bka' brgyud doctrine (Dudjom... 1991, p. 812; Dorje and Kapstein 1991, p. 402).

5. Sangs rgyas rgya mtsho composed three works on astrology and divination: the Vaidūryadkar po ("The white beryl") in which the sa chog ritual is found, the Vaidūryag.ya' sel ("The rustremoving beryl") and the Snyan sgron nyi brgya brgyad ("The two hundred and eight lamps of 
praise"). The Vaidüryadkar po (henceforth VDP) consists of thirty-five chapters in two volumes. The instructions for the sa chog appear in chapter 32, which is titled by the editor "Astrology applied to the selection of building sites and construction." The editor has further broken the chapter into twenty-nine subjects, divisions which are not indicated in the text itself. This chapter is unfortunately not illustrated in the eighteenth-century manuscript published in Gyurme Dorje (2001).

6. Dgon gnas 'debs yul sa dpyad dang sa brtag bzung gtsug lag khang rgyag stang ("Geomancy and soil investigation for determining and taking possession of the site of a monastery; the procedure for constructing a temple." Henceforth bCobrgyadkhrichen 1979). This is a chapter in his Bstan pa'i rtsa ba chos sgor zhugs stang dang bstan pa'i bsti gnas gtsug lag khang bzhengs thabs bstan pa'i bya ba las kyi 'khor lo bcas bstan pa 'dzin dang dad la mkho ba'i deb, translated by David Paul Jackson as Gateway to the Temple: Manual of Tibetan Monastic Customs, Art, Building and Celebration. bCo brgyad khri chen's Tibetan text runs alongside Jackson's translation. Translations given here are my own. According to the publishing information, the text was first published without translation in 1971. However, the author states he began his project in 1962. It is therefore possible that the lamas at Rikon had access to it. bCo brgyad khri chen is the Eighteenth bCo brgyad khri chen of dPal Na len dra monastery in 'Phen-po, Tibet, the founder of the bKra shis rab brtan gling monastery in Lumbini, Nepal, and is the head of the Tshar pa Sa skya pa order. The title bco brgyad appears to have derived from a bequest of eighteen gifts bestowed upon a Sa skya hierarch, mKhyen rab chos rje, the eighth abbot of dPal Na len dra by an emperor of China.

7. Dunhuang text IOL Tib J 447. This is a tenth-century commentary on a sädhana to the main tantra Yoga class, the Sarvatathägatatattvasamgraha. The passage approximates the sixth step of the sa chog as I envision it below, the point in which the soil is tested for drainage and other signs of auspiciousness. I am grateful to Jacob Dalton for this reference.

8. Bkra shis gter gyi bum pa bzang po'i rten 'brel gyi man ngag ("Pith instructions for the ceremony of the good auspicious treasure vase"), in volume 76 (nu) of lDil mgo mKhyen brtse's edition of the Rin chen gter mdzod. According to the colophon that falls half way through the text, the work is found in the author's rediscovered treasure called rTa mgrin gnyen po lha gsum gyi man ngag las tshogs. This is perhaps the rTa mgrin chig dril gter gzhung, which can be found in volume 40 (gu) of the Rin chen gter mdzod. The text is a brief affair of only four folio sides, including the title page. Nyang ral's own gter ma is only a page and a half; the remainder of the text is comprised by further instructions given by an unnamed editor.

9. The gSang ba'i snying po'i 'grel pa phyogs bcu mun sel, as translated and annotated in Gyurme Dorje (1987).

10. Tsongkhapa (1995) quotes extensively from Vibhūti's dKyil chog, which Lessing and Wayman (see mKhas G rubRje... 1968, p. 280 note 14) tentatively identify as Vibhūticandra's Pindịkrtasādhanapañjikā, text 1832 in the Tohoku catalogue of the Tibetan canon (henceforth Toh). A twelfth-century Vibhüticandra is credited with composing several commentaries on the Kālacakra tantra.

11. rGyud sde spyi'i rnam par bzhag pa rgyas par brjod, Toh 5489. Tibetan text and translation are in mKhasgrubrje... (1968).

12. In the Peking edition of the Tibetan $b K a^{\prime}$ ' gyur it is text number431; in the sDe dge edition it is number 807; in the Chinese Buddhist canon (the Taishō) it is number 893.

13. Possibly the dKyil 'khor thams cad kyi spyi'i cho ga gsang ba'i rgyud (Skt: Sarvamandala sāmānyavidhīnām), Peking 429, sDe dge 806, Taishō 897.

14. rDo rje las rim, ascribed to Buddhaguhya, Peking 4720 and 4761.

15. Gyurme Dorje did not locate this title. It is possible that this is the Thams cad bdud rtsi lnga'i rang bzhin/ dngos grub chen po nye ba'i snying po'i mchog/bdud rtsi mchog gi lung/ bam po brgyad pa'i mchog, pp. 2-98 in volume 34 (ngi), the 'Tshams brag edition of the Rnying ma'i rgyud 'bum.. I am grateful to Stéphane Arguillère for this reference. 
16. This is one of the four root tantras of the Mahāyoga class of tantra. In the Kaneko catalogue of the rNying ma'i rgyud 'bum it is text number 163; 190 in the gTing skyes, and 369 in the mTshams brag editions. In the bsTan 'gyur: Peking 453; sDe dge 830.

17. The Tibetan Buddhist Resource Center on-line catalogue (tbrc.org) lists three possibilities for this tantra, all belonging to the Yogatantra class: The Kye'i rdo rje mkha' 'gro ma dra ba'i sdom pa'i rgyud kyi rgyal po (Skt: Hevajra-tantrarāja-nāma), Toh 417-18, translated by 'Brog mi lo tsa ba Sākya Ye shes (992/993-1043/1072), the founder of the Sa skya sect of Tibetan Buddhism, and his teacher Gayādhara; the rDo rje mkha' 'gro gsang ba'i rgyud kyi rgyal po (Skt: Vajradākaguhyatantrarāja), Toh 389, also translated by 'Brog mi lo tsa ba and Gayādhara; and the rDo rje mkha' 'gro'i rgyud phyi ma (Skt: Vajradāka-nama-uttaratantra), Toh 371, translated by Sākya brtson 'grus and mChog gi dbang phyug (both 11th century).

18. Tsongkhapa (1995, p. 181) also states that "the mandala rites [Skt: mandalopāyikā] of Abhya, Prajñārakșita, Ratnarakșita, Nyin mo gnas 'byung, De bzhin gshegs pa'i rdo rje and so forth teach the need for investigating the serpent."

19. Evidence that the Cakrasa muvara and Kālacakra tantras provided the basis for two separate but complimentary traditions of sa chog manuals can be found in 'Jam mgon kong sprul Yon tan rgya mtsho's autobiography. In relating the events around the consecration of the site for Tsā 'dra rin chen brag, his retreat hermitage above dPal spung monastery in sDe dge, Kong sprul writes: "The vajra master Nges don did a sa chog according to Cakrasa muvara and I did a sa chog according to the Kālacakra" ('Jam mgon kong sprul Yon tan rgya mtsho 1997, p. 205).

20. Indian origins for the sa chog extend well beyond Buddhist tantric literature. Ling (1997, p. 19) gives examples from the Pāli canon in which similar rites for pacifying earth spirits prior to construction are condemned as low arts. As far as non-Buddhist sourcesare concerned, the field is vast. Indra subdued a cosmic serpent, Vrrta, to create the universe (Boord 1993, p. 39). A closer relative might be the Vāstupurușamandala, a rite performed before the construction of Indian religious buildings. Here the figure mapped onto the ground is Purusa, the "cosmic man". See Kramrisch (1946) and Daniel (1984) for a discussion of the rite. The full history of the relationship between Indian and Tibetan mythology in regards to such figures as the nāga and the Vāstupurușamandala is still poorly understood.. Tibetan geomancy has roots in China as well, a fact acknowledged by Karma Chags med (SCMB, p. 95.1). Legend speaks of the Tang Princess Wencheng performing geomantic rites to enable the construction of the Lhasa Jo khang, an event discussed by Bacot in his 1935 "Le mariage chinois du roi tibétain Sron bcan sgam po". On Wencheng Gongzhu's geomancy see also Gyatso (1987), Sperling (1976), Miller (1998) and Wangdu (2002). Chinese astrology is one of the two main branches of the Tibetan tradition (the other being Indian, and the two being known as "black" and "white", respectively).

21. Van Dyke (1997, p. 185) tells us that the abbot ofRikon, Geshe Urgyen Tsheten, consulted with specialists in Dharamsala and had brought with him "photocopies of prayers and commentaries of the necessary foundation rituals to Switzerland." Not being present at the ritual she did not see what these "prayers and commentaries" were, and her sources do not tell. She does mention (p. 191) that the image of the serpent drawn at Rikon derived from the image in the Vaidüryadkar po "which the abbot had described to a Tibetan painter in India. The painter interpreted the description" and his drawing became the pattern for the figure at Rikon.

22. Sangs rgyas rgya mtsho himself likely drew from Tsong kha pa's text, as there are numerous similarities between his instructions and those of Tsong kha pa and Vibhūti, notably in the warnings, where the wording of the consequences for digging in the wrong places is nearly identical.

23. At Rikon this step was performed a year in advance: the late junior tutor to the Dalai Lama, Yongs 'dzin Khri byang rin po che (1901-1981), traveled to Rikon in 1966 to supplicate the earth goddess with prayers and offerings and dispel negative forces from the site, though Van Dyke does not speculate on what form those prayers took (Van Dyke 1997, p. 185). 
24. Padmasambhava's incarnation during the third lunar month.

25. Unclear: phyag g.yas sa la brdab pa yis/ sa gas rnam pa drug tu g.yos.Unclear: phyag g.yas sa la brdab pa yis/ sa gas rnam pa drug tu g.yos.

26. Klong chen pa and mKhas grub rje both include this step in the preliminaries to laying a mandala. According to Klong chen pa, after concealing treasure and consecrating the ground: "The ritual of the goddess of the earth should be performed: the yogin must indeed conquer negativity in the manner of the Buddha who previously requested the site at Vajrāsana and conquered Māra at the time of attaining buddhahood. The golden goddess (of the earth) is visually created, holding a vase and riding on a pig. Once she has been invited, offerings and eulogies are made to her, along with the words: 'Permit me, such and such a person of indestructible reality, to build a mandala in the vicinity of this site!'”(Gyurme Dorje 1987, p. 757). mKhas grub rje writes: "Without exception, it is mandatory in the ritual of all mandala to have conviction that permission has been granted. Moreover, in the Samvara, Kälacakra, etc., one asks the Earth Goddess for permission. In particular, in the Samvara one says, 'O Sugata, [I] beg the site', which amounts to asking permission of a supra-mundane being; and in the Kālacakra there is something consistent with that." (mKhasgrubrje... 1968, p. 279).

27. This is likely a reference to the tortoise divination, one of the earliest and most common forms of divination practiced in Tibet. See Gyurme D orje (2001, chapter 2), and also Parfionovitchetal. (1992) for its medical applications.

28. The text lists, among others, gu gul which Parfionovitchetal. (1992, pp. 332, 334) say is Frankincense (Balsamodendron mukul) and ri sho, which they say is mountain sorrel (Ligularia laesicotal).

29. Van Dyke tells us that at Rikon the site for the grid was prepared in a manner inconsistent with the "canonical texts." First, the grid, "according to previous traditional theory, if not practice", should have been laid out where the main shrine would later stand. Rather than orienting the sides of the grid, and the plan of the temple, with the cardinal directions, they were suited to the lay of the land, which at Rikon was a southward sloping hill. The site of the grid was dug out, leveled, and a layer of plaster dust was applied. The lines of the grid were then laid out with string dipped in colored powder, beginning on the eastern side. Each edge was divided into ten hand-lengths, and each of those further into nine thumb-widths, creating a grid with a total of 360 small squares around the perimeter (Van Dyke 1997, pp. 188-191). She considers the significance of the number of squares of the grid and the differences between grids laid for houses, temples, mandalas and so forth. For the most part these variations appear to have arisen through error on the part of monks, not from divergent tradition; the four manuals are clear on the number of squares.

30. Kramrisch (1946, pp. 89-92) offers numerous names of deities in the corners of the Vāstupurușamandala grid, none of which precisely matches these four terms. Agni, the Vedic fire god, is prominent in several of them.

31. Mtho and cha chen appear to be synonyms; the VDP uses cha chen and mtho interchangeably, and Van Dyke's sources affirm this. However Chos kyi grags pa has doubts as to whether the " $m$ tho" used in his scriptural sources for the measurement of the serpent's body is the same thing as a cha chen: gzhung du klu yi rgyal mo yi/ lus tshad mtho bcu gsungs pa'i don/ cha chen grangs yin mtho dngos min (SBLP1, p. 129; SBLP2, p. 99.1-2; SBLP3, p. 476.2).

32. At no point in either Van Dyke's narrative nor our manuals is the southeast corner clearly identified as the corner of "fire." However bCo brgyad khri chen instructs: "In the last winter month, the [zodiac] house of Virgo, begin with "fire," circle to the right and mark one cha chung for each zodiac day." Jackson interjects that "fire" is the southeast corner. This is not in bCo brgyad khri chen's Tibetan, but because the translator tells us he worked closely with the author, the insertion probably represents oral instructions (bCobrgyadkhrichen 1979, p. 32). 
Tsongkhapa (1995, p. 183) supports this as well: "Lay the squares for the three months in sequence, starting in the southeast..."

33. Chos kyi grags pa explains the variations as being due to the fact that geomancy came to Tibet from numerous sources such as the Indian Kālacakra system and the "old and new Chinese" systems, and further due to the differences in the old and new translations of the secret mantra.

34. Klong chen pa's orientation agrees with that of Chos kyi grags pa and Sangs rgyas rgya mtsho (Gyurme Dorje 1987, p. 759), as does Tsongkhapa (1995, p. 184), and mKhasgrubrje... (1968, pp. 280-281).

35. Van Dyke hypothesizes that this apparent laxity of the Rikon lamas may have been because of the nature of the building, citing Kramrisch's claim that the Vāstupuruṣamandala does not rotate with the seasons if the building is a temple (Van Dyke 1997, p. 194). The ritual manuals, however, make no such exception, and must be favored over Indian comparatives. Either the lamas were poorly informed, or the dangers spelled out in the texts are not taken so literally, and the lamas felt it safe to cut corners, so to speak.

36. Wangmo (1985, pp. 109-110) writes that in the construction of Bhutanese houses the figure is not actually drawn; instead the astrologer need only count the squares of the grid to calculate where the first digging is done.

37. According to Nebesky-Wojkowitzthese deities are associated with the eight great cemeteries of Indian cosmology and are found in the retinue of Mahākāla. These same eight deities, which he also calls "companions of Varuna", are also common participants in rain making rituals, during which they receive offerings (Nebesky-Wojkowitz [1975] 1993 pp. 265, 477-478).

38. As is Tsong kha pa's description (mKhasgrubrje... 1968, p 281; Tsongkhapa 1995, p. 183).As is Tsong kha pa's description (mKhasgrubrje... 1968, p 281; Tsongkhapa 1995, p. 183).

39. According to the Bod rgya tshig mdzod chen mo (1993, p. 467) this is a wrathful deity.

40. The artist helps us here by drawing a dashed line running from the serpent's eyes to the spot.

41. This is a difficult term to translate. The Bod rgya tshig mdzod chen mo (1993, p. 2903) definition suggests it is a vital spot identified by a geomancer, a geomantically desired spot.

42. bCobrgyadkhrichen (1979, p. 32). The illustration in his manual (fig. 1) confirms this: while the figure is drawn in reverse (the right hand is to his ear, the left is at his waist holding the jewel, and facing to the right) the vital spot is marked in the correct location under the left armpit.

The illustration (fig. 3) in Meyer and Jest (1987, p. 138) is similar to that in bCo brgyad khri chen: it is the serpent's right hand that is raised, though not to his ear, and the vital place is marked under that arm.

The measurements at Rikon seem to have followed Sangs rgyas rgya mtsho (fig. 2) and bCo brgyad khri chen (Van Dyke 1997, p. 195). Tsong kha pa, quoting Vibhūti, gives slightly different measurements (Tsongkhapa 1995 p. 184; mKhasgrubrje... 1968 p. 280-81).

43. Tsongkhapa (1995, p. 184) likewise simply says to offer milk and so forth.

44. Chos kyi grags pa's SBLP, however, contains a somewhat different approach. Rather than inviting the buddhas and bodhisattvas to the site as was done at Rikon, the ritualist is instructed to invoke the serpent deities themselves, in a move that seems to relate more to Karma chags med's invocation to the earth goddess in Step one. Following an invocation to the serpent and the Eight Great Nāgarāja (see above) in which they are described in detail, the text reads:

By means of a light from a seed center in one's own heart, the great serpent together with the eight nāga appear in a state of contemplation. Invite [them] at once, [reciting]: dza hūm bam ho and relax into non-duality. With hands together, express the mudrā of the five pointed vajra and recite three times: bhūmipati nāgarāja saparivārasamaya rakșaṇtu hūm ho hūṃ [thereby] bind-ing them under oath. [Recite also:] om mahābhūmipati nāgarāja saparivāra argham pratīccha svāhā and so forth, venerating up through to the word śabda. Having made the blessing of sprinkling the milk onto the gtor $m a$ and the six syllable mantra and six mudrā, make the mudrā of the open-palmed vajra 
and recite twenty one times: ombhūmipati nāgarāja saparivāra ìmam balim ghrihaña khakha khāhikhāhibhujatha pibatha viśvasugāmaguna pūja pratīccha svāhā.Holding gtor ma in offering, recite from the Yid la 'dod pa kun 'grub mdzod [Treasury of all accomplished desires, text unidentified] holding a vajra and bell: "Emaho! Jewelled lord who wears an ocean robe, earth lord who protects all as he likes, with a gait of a serpent, holder of many variegated precious ornaments, supporting with your body the Eight Great Nāgarāja, your torso [is that of] the earth rāhu, with the powerful divine poison, a quivering cloud-like hood; your lower body with the powerful attribute of bum na can [?] I pay homage to you. Because the foundation of all the riches of sentient beings depend on you, I, the master offer this earth-accomplishment celebration in order to benefit beings." Praying like this, think that the king of the earth lords grants his permission [saying]: "May you, vidyādhara, make use of this place of attainment in whichever way you like" (SBLP1, pp. 133-134; SBLP2, pp. 103.4-105.1; SBLP3, pp. 481.5-483.1).

Regarding the bum na can, in Klongchen pa's description of the earth goddess she carries a vase and rides a pig (Gyurme Dorje 1987, p. 758). Could there have been a confusion in the textual transmission, such that Choskyi grags pa could confuse the serpent with the earth goddess and describe the serpent as having the attributes of a vase (bum) and the lower body of a pig (sna can)? 45. Van Dyke writes that because the monks wished to preserve the image of the serpent for dignitaries who would visit the next day, the monks who performed this step only superficially disturbed the figure, only taking a few handfuls of soil. One monk grasped the plaster dust from the vital place and another "scattered the gathered earth, circumambulating around the square platform and the whole boundary of the future building, thereby defining the extent of the realm that the sa bdag was asked to relinquish. Both monks visualized themselves as generous and gentle deities while they entreated the sa bdag to leave." They repeated this four times, scattering the earth in the six directions. Perhaps it was due to the demands placed upon them by the desire to preserve the figure that the monks at Rikon behaved so peacefully. Van Dyke's informants themselves indicate an alternate reading of the event, telling her that "the earth can be 'stabbed' or grasped three or four times" (Van Dyke 1997, pp. 99-100).

46. Karma chags med follows this with "the method for purifying the soil". The purification involves visualizing the five buddhas on their thrones and flanked by bodhisattvas of the ghanta family (SCMB, p. 92.3-6). They emit light rays that purify the site, and homage is sung to them and all buddhas of the ten directions, etc. (ibid., p. 90.4-5). The deities then dissolve into the ritualist, and thus "in that way the ground has been consecrated" (ibid., pp. 92.2-94.1).

47. Tsong kha pa and Vibhūti both instruct the one who digs to visualize the Destroyer of Obstructers, though like Sangs rgyas rgya mtsho neither is explicit as to whether the digger is to visualize himself as this deity (Tsongkhapa 1995 pp. 184-185). A noteworthy difference between Tsong kha pa and Vibhūti's presentationsof the sa chog is that much of it is mentally created. Tsong kha pa here instructs: "Imagining (bsams) the serpent as [previously described], make offerings of milk and so forth. The one who digs should generate [a vision of] the Destroyer of Obstructers. Imagining a pickax marked with vajra, one's right hand above, left below, strike. One should face northeast. Having taken the soil of the fourth strike (brgyab), with a peaceful mind fill a gtor ma with it or throw it beyond the squares of fire etc. With the soil of the fifth strike, after scattering it in the center all the workers are permitted to dig in all cardinal and intermediate directions." Vibhūti, however, only instructs that the soil should be "mentally scattered": "The person [digging] should cultivate [a visualization of] the Destroyer of Obstructers; the hero takes a pickax with the mark of a vajra in hand, his left hand below. With that the host of demons are fearful and are driven back. Facing northeast, the soil taken by the fourth strike should be placed inside a gtor ma with a peaceful mind or cast beyond the edges of fire and so forth. The hero skillfully mentally scatters the soil of the fifth strike into the center of the foundation. At the fifth strike, the many workers should dig the cardinal and the intermediate directions and so forth." 
48. mKhas grub rje gives instructions for digging: In order to "line" the "armpit" (kaksa) of the "breast goer" (uraga) at the place where one commences to dig, one strikes a line (*sūtra-nyāsa) to determine the breast goer. When one has lined its armpit, he thereupon digs out first two or three shovelfuls, after which he may proceed with digging wherever he wishes without risking offence to the field protector (mKhasgrubrje... 1968, pp. 279-281).

49. This step apparently was not included in the film of the Rikon sa chog performance. Van Dyke (1997, pp. 199-200) bases her description of the soil testing on the translation of bCobrgyadkhrichen (1979) and Meyer and Jest (1987).

50. Chos kyi grags pa does not mention this aspect of the soil test. Instead he proceeds to the warnings regarding digging in the wrong place (to be discussed below). Karma chagsmed mentions a hole, but its origin is left unexplained (SCMB, pp. 94.1-95.1).

51. Khung bur myur du slar blug pas/ sa de lhag par gyur na bzang/ ma khengs gyur na dman pa'o (VDP, p. 394.2). The Dunhuang manuscript IOL Tib J 447 contains a passage very similar to the above, at a point in which the text explains how to locate a suitable place to practice the sādhana for the Sarvatathāgatatattvasamgraha: "As for finding places that are indicated in the Kriyā scriptures, wherever one digs a hole in the ground, having refilled it with earth, if it is full or there is extra, then it is an indicated site. If it is not full, it is not indicated. If jewels, flowers, or chunks of flesh [?] come out of the earth, it is the indicated site. If charcoal or bones appear, it is not indicated." Kri ya'i gzhung gi brtags pa'i gnas btsal ba ni sa gru gang brkos na/ sa phyir gang nas/gang 'am lhag na/ sa brtags pa yin/ ma gang ma brtags/ sa'i nang nas rin po che dum bu dang me tog dang sha dum byung na brtags/ sol ba dang rus pa byung na ma brtags (p. 7.8-10).

52. The refilling the hole with soil as well as testing the soil's water-bearing capacity by pouring water into the hole is also found in the Vāstupuruṣamaṇdala rite. In the Vāstupuruṣa pūjō as described by Daniel the replacement of the soil and the pouring in of water are combined. Here the soil is put back so as to form a mound in the center, and water is poured in such a way to create a clockwise current around it. This island represents the Vāstupuruṣa. A flower is then dropped in by the $\bar{a} c \bar{a} r i$, and must circumambulate the island three times. Based on the site where it lands forecasts are made regarding the potential for benefit or harm (Daniel 1984, p. 118).

53. Vibhūti, as quoted in Tsongkhapa (1995, p. 185), includes a reference to the serpent's fear at the very point when the first digging is done: the master, by having visualized [himself as] the Destroyer of Obstructers, and holding the pickax as described elsewhere, inspires fear in the "demon", who is then driven back (mi ni bgegs mthar byed kyi rnam par bsgom/ dpa' bo'i lag pa tog tse rdo rjes mtshan/ lag pa g.yon pa 'og tu byas nas gzung/ de yis bdud kyi tshogs ni skrag cing zlog). However, Tsongkhapa, in his own words (1995, p. 184), does not mention the serpent being afraid. Meyer and Jest (1987, p. 154) write that if the water drains quickly it is a sign that the serpent is starving.

54. gNas der bgegs bsal srung 'khor sgom/ bkod bas sa bzung phur gdab sogs (bCo Brgyadkhrichen 1979, p. 33).

55. (SBLP1, p. 134; SBLP2, p. 105.4-5; SBLP3, p. 483.5-6). The inclusion of the colors here is only slightly clarified by Sangs rgyas rgya mtsho, who writes: "To a small amount of the soil which was dug one should take hold of the good elements of dark oil and the five precious colors: white [for] kșatriya, yellow vaiśya, red śudra, blue brahmin and black outcaste, each glossy and attractive, as attainment attributes (de yang khru gang tsam brkos la/ snum nag rin chen kha dog lnga/ byung bzang dkar po rgyal rigs dang/ rje rigs ser po dmangs dmar po bram ze sngon po gdol pa nag snum dang yid 'ong so so yi/ dngos grub mtshan mar bzung bar bya) (VDP, p. 394.1-2).

56. Sangs rgyas rgya mtsho does give instructions for a treasure-vase offering immediately preceding the sa chog instructions: "Moreover, for the system of taking land, [use] for a small ransom a small sanctified vase. Draw an eight-spoked wheel, and eight-petaled lotus, and a sun and moon on paper. Fill the inside of an egg with varieties of medicine and grains and the five varieties of jewels. On the outside draw the figure of a bird. Cover it with a white cloth and in the 
center consecrate it with treasure. Bury this in the four directions, and outside of that [images of] the twelve earth lords, all the same color. At that time, in that area, bury one with a tip, and recite the following evil promise, drinking poison with one's lips: 'Ho! By placing this precious small ransom into the earth, earth lord, may you be a benefactor possessed of treasure for this precious soil. If all die, you too shall die. If [all] are destroyed, you too shall be destroyed"' (VDP, p. 390.4-6).

57. Such a vase rite can be found in volume 76 of the Rin chen gter mdzod in a section on pacification rites that might be used in concert with, or in place of, a sa chog. For example, the text Kong sprul placed before Nyang ral's, a text titled Zhi ba zin by Yongs grub rdo rje, is a standard feast offering for a peaceful deity to be performed when constructing a house, taking a wife and the like. It promises that for this pacification ritual no sa chog nor earth-requesting ( $s a$ slong) rite need be performed.

A summary of Nyang ral's text is as follows: first the vase is prepared, decorated with the eight auspicious symbols, an eight-spoked wheel on the cover, with the mantra om surya candra ye swahi written in the center, with other mantra around its edges. Around the edges, in Sanskrit letters, are written: "Gods and demons of the realm in the southern continent, Jambudvipa and the eight classes of gods and rakșaof the realm in the kingdom of mNga' ris and Tibet in general, and the gods and demons of the realm in this valley in particular, and [those] of whatever place, but especially the gods and demons of the realm in this estate, to you [I] offer this precious treasure. May you bring about the property of both the people and their wealth. Pacify illness and harm. Make the life force flourish, well-being and happiness remain for a long time. Accomplish all wishes like precious jewels." The vase is then filled with "whatever beings offer," but should include "grain taken from a house of abundant human wealth," as well as "gold, silver, copper, conch, crystal, lapis lazuli, iron, and so forth." Five vases in total are prepared, one to be buried in the center of the site, and one in each of the four cardinal directions. The vases of the five different locations have specific instructions: "Paint a burning jewel directly on the central vase. Paint the four protector gods in the four directions. Then on the eastern [vase] draw a grey tiger with white wash. On the southern draw a dragon with indigo. On the western draw birds with red ochre. On the northern draw a turtle with black ink." The treasure section of the text then concludes with the promises that "by burying them in this manner, wealth, pleasures and the collection of the three excellences will arise" (BGB, pp. 38.1-39.5).

58. I do not understand clearly why the ritualist is here instructed to "feign" offering the vase, but it compares well to the performance at Rikon, where the vases were literally only symbolically offered the first day, and actually buried later.

59. De nes kham lnga'i shul de ru/ bum gter lag len ltar bcos pa/ legs par bcug pa sa yis dgab (SBLP1, p. 135; SBLP2, p. 106.1; SBLP3, p. 484.2).

60. Shul der zug rngu dbyung ba'i ched/ bum gter sba zhing gtor ma dbul (VDP, p. 394.3).

61. Because Swiss engineers and construction crews began work at the site a week prior to the sa chog, the vase ceremony, the compensation for the seizure of the land, was done separately, on June 30th. A lotus was drawn on the base of the pit and flowers were strewn in. The vases had been prepared a week earlier with substances brought from India, and included the five kinds of metals, five grains, cloths, medicinal herbs, soil from holy sites, the three whites and the three sweets (a common tantric offering), and medicines prepared especially for the serpent. They were then wrapped in ribbons and a single shovel of earth was thrown on top, as the actual insertion would take place two days later for the benefit of the visitors (Van Dyke 1997, pp. 202-203).

62. In place of mi mngon bya the first two editions read mi mngon dbyings ("empty space").

63. This line is different in each edition. The SBLP1 reads gang byung 'ol tshod bgyis pa na; the SBLP2 reads gang byung tshe 'ol bgyis pa ni; and the SBLP3 reads gang byung cho rol bgyis pa na. I have tried to render it in what makes the best sense in the context. 
64. Tsong kha pa (1995 p.185), quoting again from Vibhūti, also warns agains digging in the nine places, but is no clearer : gal te lto 'phye'i rgyal po gnas pa yi/ cha dgu'i sa yi cha la brkos na ni...

65. There are prohibitions against digging in the Pāli Patimokkha, for example, where it is classified as a pacittaya offense, one which must be confessed. This, however, appears to have been because at the time the text was redacted the soil itself was thought to be alive. See Thanissaro Bhikkhu (1994). I am grateful to Patrick Pranke for this reference.

66. This is the story of the clash between good and evil some time after the beginning of the current world system. After a lengthy reign of terror in which the malignant deities Siva (Bhairava/Rudra) dominated this southern continent of Jambudvipa, the Buddha takes the form of Heruka ( Cakrasa mvara/Vajradhara) to defeat him. The enemy together with his retinue are killed and then resuscitated and bound by oath to the Buddhist community. On this myth see especially Kapstein (1992), Stein (1995), Mayer (1998). On the importance of the myth in Tibetan sacred geography, see MacDonald (1990), Huber (1990 and 1994a), and Buffetrille (1994).

67. See especially Buffetrille (1997, 1998 and 1999); Epstein and Peng (1994); Huber (1994b, 1994c, 1997a, $1997 b$ and 1999); Kapstein (1998); van Spengen (1998); Steinman (1998).

\section{ABSTRACTS}

The Tibetansa chog, or "soil ritual", customarily performed prior to the construction of a temple or house, is a Buddhist ritual for organizing space. The rite calls to the surface of the earth the subterranean serpent deity ( $k l u$, related to the Indiannāga), determines its orientation in space and time, and subjugates it through a series of steps characterized by both violence and veneration. The rite is a means by which Tibetan communities preserve and contain the power of the soil in such a way that orients it towards human interests. The article makes use of numerous Tibetan ritual manuals from various authors and traditions, as well as a reported 1967 performance of the rite in Rikon, Switzerland, to outline the sa chog rite. The author identifies eight steps: the selection of the site and the performance of preliminary rites; the laying of the grid; the drawing of the serpent and the identification of the vital place; the feast offering for the deities; the stabbing of the vital place; the testing of the soil for omens; the vase offering; and the release of the serpent. While no single text referenced contains all eight of these steps, the performance of the sa chog in Switzerland as described by Van Dyke justifies taking them together as an amalgamated whole.

Le sa chog tibétain, ou « rituel du sol », généralement exécuté avant la construction d'un temple ou d'une maison, est un rituel bouddhique d'organisation de l'espace. Le rite convoque à la surface de la terre la divinité serpent souterraine ( $k l u$, apparentée au nāga indien), détermine son orientation dans l'espace et le temps, et la soumet en plusieurs étapes caractérisées à la fois par la violence et la vénération. Ce rite est un moyen grâce auquel les communautés tibétaines préservent et maîtrisent la puissance du sol de manière à l'orienter en direction des intérêts humains. Pour expliquer le rite du sa chog, cet article utilise de nombreux manuels rituels tibétains provenant de divers auteurs et traditions, ainsi qu'une étude de ce rite exécuté en 1967 à Rikon, en Suisse. L'auteur identifie huit étapes: le choix du site et l'exécution des rites préliminaires; la mise en place de la grille; le dessin du serpent et l'identification des endroits vitaux; le festin d'offrandes aux divinités ; le coup porté à l'endroit vital ; la lecture des présages par examen du sol; l'offrande du vase et la libération de la divinité serpent. Alors qu'aucun des 
textes considérés n'expose la totalité des huit étapes, l'exécution du sa chog en Suisse tel qu'il a été décrit parVan Dykejustifie de considérer leur ensemble comme un tout cohérent.

\section{INDEX}

Keywords: soil ritual, organization of space, Tibetan communities, exile Mots-clés: rituel du sol, organisation de l'espace, communautés tibétaines, exil nomsmotscles Amdowa, Khampa, Tibétain

Subjects: bouddhisme, frontières, géographie, écologie, identité, nation, nationalisme Geographical index: Chine, Khams, Himalaya, Tibet, Amdo

\section{AUTHOR}

\section{ALEXANDER GARDNER}

Alexander Gardner prépare sa thèse à l'Université du Michigan. Il travaille sur les vingt-cinq lieux saints du Khams (Tibet oriental) et leur place dans la formation de l'identité régionale, ainsi que sur les débuts de l'établissement de la tradition ris med (mouvement tibétain non sectaire) 